\title{
Synnyttäminen ja raskaus oppimiskokemuksena
}

Tuula Piensoho (2001) Äitiyden alkumetrit Naisten raskaudelle ja synnytykselle antamat merkitykset ja oppimiskokemukset. Helsingin yliopiston kasvatustieteen laitoksen tutkimuksia 176.

\section{Kirjassa analysoidaan} kertomusten perusteella raskauden ja synnytyksen merkityksiä naisille. Eri aikakausien tarkastelussa verrataan naisten antamien merkityksien eroja ja samankaltaisuuksia toisiinsa.
Erityisen kasvatustieteellisen näkemyksen työhön tuo raskauden ja synnyttämisen tarkastelu oppimiskokemuksena.

Tutkimus on monitieteinen. Se sisältää aineksia kasvatustieteen lisäksi naistutkimuksesta, hoitotieteestä sekä lääketieteestä. Lähtökohtana on tutkijan voimakas omakohtainen kokemus, joka on vaikuttanut tutkimuksen eteenpäinvievänä voimana.

\section{Piensoho kertoo} tutkimuksensa tarkoituksena olevan kuunnella raskaana olleiden ja synnyttäneiden naisten ääniä sekä etsiä ehjän raskaus-, synnytys- ja äitiyskokemuksen ehtoja. Ehjällä kokemuksella tutkija tarkoittaa hyvää raskaus- ja synnytyskokemusta.

\section{Tutkimuksen tehtävät} ovat seuraavia. Mitä raskaus ja synnytys merkitsevät naisille? Ovatko eri aikakausina naisten merkitykset erilaisia? Millaisia ovat naisten raskauden ja synnytyksen oppimiskokemukset? Tutkimuksen menetelmällisenä lähestymistapana on fenomenografinen tutkimusote, 
jota on käytetty kahden ensimmäisen ongelman ratkaisussa. Tässä osassa tutkimusta sen aineistona ovat 167 naisen kirjoittamat kertomukset heidän raskausajoistaan ja synnytyksistään. Aineisto alkaa 1930-luvulta ja päättyy nykyaikaan. Kolmannen ongelman ratkaisussa on käytetty 1970ja 1980-lukujen kertomuksia, joita on sata. Niiden analyysi perustuu Jarvisin, Mezirowin, Martonin ja Boudin teorioista koottuun jaotteluun, jota käytetään deduktiivisen sisällönanalyysin pohjana. Muuten aineiston analyysi muodostuu kertomuksista muodostetuista kategorisoinneista.

\section{Tutkimuksessa}

yhdistetään kahdesta filosofisesta taustasta lähtöisin olevia menetelmällisiä ratkaisuja.

Tutkimuksen menetelmävalinnat on tehty tutkimuksen prosessin kuluessa täydentämään aineistoa. Fenomenografian avulla tutkimuksen ainekset on koottu yhtenäiseksi tutkimukseksi.

\section{Naisten raskaudelle}

antamat merkitykset aineistossa on kategorisoitu yhdeksään luokkaan, joista lyhyesti seuraavassa. Suomessa raskaus on voinut merkitä naisille tietämättömyyttä 1930-1940 -luvuilla, mutta myös vielä 1960 -luvulla. Osa äideistä kertoo raskauden aikaisista valmentautumistarinoista, joissa he valmistautuvat mm. kirjallisuuden avulla synnytykseen. Jotkut naisista kertovat raskauden sujuneen maanläheisesti muun elämän ohessa. Aineistolainoista saa käsityksen, että kyseessä olisi maaseudulta kotoisin olevat naiset. Toisille naisille raskaus on merkinnyt kriisivaihetta elä- mässä, joka on voinut kärjistää myös muita ongelmia. Raskaus on saattanut merkitä myös torjuntaa ja kaaosta. Osalle äideistä raskaus on merkinnyt iloa tulevasta äitiydestä. Raskaus saattoi merkitä myös ristiriitoja. Vielä 1970-1980 -luvuilla avioliiton ulkopuolinen raskaus on voinut merkitä äidille vaikeuksia ympäristön kanssa. Raskaus on toisissa tapauksissa saanut merkityksensä parisuhteen kautta, jolloin isän merkitys raskauden aikana ja synnytyksessä on korostunut tukijana ja auttajana. Raskaus on voinut merkitä äideille myös fyysisiä ongelmia ja keskenmenon uhkaa.

\section{Äitien antamat}

merkitykset synnytykselle Piensohon on luokitellut seuraavasti. Synnytys on äitien merkityksenannossa ollut $\mathrm{mm}$. tietämättömyyttä ja jopa häpeää. Samalla se on merkinnyt nuoruuden päättymistä. Synnytys on merkinnyt myös tervettä lasta. Se on ollut toisille naisen elämään kuuluva luonnollinen asia. Synnytyksen merkityksissä painottuu myös vuorovaikutus tai sen puuttuminen. Synnytys on voinut merkitä myös voimakkaita epäonnistumisen tunteita ja huonommuutta. Synnytys on toisille ollut "naisten oma asia”, joka sisältää luovuutta ja huumoria. Toisille naisista synnytys on merkinnyt feminististä kokemusta. Synnytys on merkinnyt myös nautintoa ja vaikeuksien voittamista tai se voi merkitä nautintoa ja seksuaalisuutta. Toisaalta synnytys voi merkitä kriisivaihetta, epäkohtien huomaamista ja muutosta.

Raskauden ja synnytyksen kokemukset ja niille annetut merkitykset vaihtelevat suuresti eri kategorioissa, mutta tutkijan löytämien merkityksien ja niiden muodostamien luokkien väliset erot eri aikakausina ovat pienet.

\section{Tutkimus kertoo paljon} tietoa naisten myönteisistä ja kielteisistä raskaus- ja synnytyskokemuksista. Naisten kielteiset kokemukset ovat jääneet heille vuosikausien painolastiksi ja painajaisiksi. Kun työn ideana on löytää hyvä raskaus- ja synnytyskokemus eli ehjä raskaus- ja synnytyskokemus, tutkimus päätyykin käsittelemään sitä, miten asioiden pitäisi olla. Tulostensa pohjalta tutkija antaa ohjeita siitä, miten kehittää toimintaa kohti eheämpää raskaus- ja synnytyskokemusta. Tutkimuksen anti onkin sen sovellettavuudessa.

\section{Tutkimuksen aineisto on}

laaja ja sitä on käsitelty monipuolisesti, mutta silti jää miettimään kirjaa lukiessa, ovatko aineiston kirjoittamiseen osallistuneet myös ne, joiden synnytyskokemukset ovat olleet kaikista traumaattisimmat. Saattaa olla, että kaikki eivät ole lainkaan pystyneet kirjoittamaan synnytyskokemuksistaan vuosienkaan jälkeen. Jäänkin pohtimaan sitä, minkälainen on ollut hoitajien ja läkärien näkökulmasta "hyvä synnyttäjä" tutkittuina aikakausina ja nyt?

\section{Kirjan esiin nostattama} kysymys siitä, miten tehdä synnyttävästä naisesta subjekti objektin sijasta sisältää tärkeän viestin hoitohenkilökunnalle ja lääkäreille.

\section{Soila Judén-Tupakka}

